\title{
PENERAPAN MODEL STUDENT TEAMS ACHIEVMENT DIVISION MELALUI LKS BERBASIS MASALAH TERHADAP KEMAMPUAN BERPIKIR KRITIS SISWA PADA MATERI EKOSISTEM DI KELAS VII SMP NEGERI 2 JALAKSANA
}

\author{
Nurwulan Saputri ${ }^{1)}$, Ondi Suganda ${ }^{2)}$, Lilis Lismaya ${ }^{3)}$ \\ ${ }^{1}$ Mahasiswa Program Studi Pendidikan Biologi FKIP, Universitas Kuningan \\ ${ }^{23}$ Dosen Program Studi Pendidikan Biologi FKIP, Universitas Kuningan \\ Email : ondi.suganda@uniku.ac.id \\ Email : lilis.lismaya@uniku.ac.id
}

APA Citation: Saputri, N., Suganda, O., \& Lismaya, L. (2018). Penerapan Model Student Teams Achievment Division Melalui Lks Berbasis Masalah Terhadap Kemampuan Berpikir Kritis Siswa Pada Materi Ekosistem Di Kelas VII SMP Negeri 2 Jalaksana. Quagga: Jurnal Pendidikan dan Biologi, 10(2), 45-51. doi: 10.25134/quagga.v10i2.1340.

Received: $31-07-2018$

Accepted: $31-07-2018$

Published: $31-07-2018$

\begin{abstract}
Abstrak: Penelitian ini bertujuan untuk meningkatkan kemampuan berpikir kritis siswa pada konsep ekosistem melalui penerapan model Student Teams Achievment Divisionyang disertai dengan LKS Berbasis Masalah. Penelitian ini merupakan penelitian Eksperimental dengan desain penelitian yaitu pretest-posttest control group design.Populasi penelitian semua siswa kelas VII SMP Negeri 2 Jalaksana di tahun pelajaran 2015/2016. Pengambilan sampel dengan tekhnik cluster random sampling. Sampel penelitian dari kelas VII C sebagai kelas kontrol dan kelas VII D sebagai kelas eksperimen. Pengumpulan data dengan tes uraian (pretest-posttest), LKS berbasis masalah, lembar observasi guru dan siswa, dan angket respon siswa terhadap proses pembelajaran. Analisis data diambil menggunakan uji $t$, berdasarkan uji $t$ didapatkan $t_{\text {hitung(4,5) }}>t_{\text {tabel(2,005) }}$ dengan taraf signifikan 5\% yang artinya Ho ditolak dan $\mathrm{H}_{1}$ dengan nilai gain kelas eksperimen lebih besar daripada kelas kontrol yaitu 0,48 dalam kriteria sedang dan kelas kontrol 0,22 dalam kriteria rendah, hasil analisis LKS berbasis masalah mencapai persentase 75,3\% dalam kriteria baik, lembar observasi guru dan siswa mencapai $89 \%$ dan $72,5 \%$, dan hasil analisis angket respon siswa mencapai $87 \%$. Hal diatas menunjukkan bahwa penerapan model Student Teams Achievment Division yang disertai dengan LKS Berbasis Masalah dapat meningkatkan kemampuan berpikir kritis siswa pada materi ekosistem.
\end{abstract}

Kata Kunci : Model STAD, LKS Berbasis Masalah, Kemampuan Berpikir Kritis

Abstract: This study aims to improve students' critical thinking skills in the concept of ecosystems through the application of the Student Teams Achievement Division model which is accompanied by Problem Based LKS. This research is an experimental study with a research design that is a pretest-posttest control group design. The population of the research is all students of class VII of Jalaksana Public Middle School 2 in the 2015/2016 school year. Sampling using cluster random sampling technique. The research sample was from class VII C as the control class and class VII D as the experimental class. Data collection with description tests (pretestposttest), problem-based LKS, teacher and student observation sheets, and student response questionnaires to the learning process. Data analysis was taken using $t$ test, based on $t$ test obtained $t_{\text {count }}(4.5)>t_{\text {table }}(2.005)$ with a significance level of 5\% which means $H o$ is rejected and $H_{1}$ with the gain value of the experimental class is greater than the control class which is 0.48 in the criteria of being and the control class of 0.22 in the low criteria, the results of the problem-based LKS analysis reached a percentage of $75.3 \%$ in good criteria, the teacher and student observation sheets reached $89 \%$ and $72.5 \%$, and the results of the student response questionnaire analysis reached $87 \%$. The above shows that the application of the Student Teams Achievement Division model accompanied by Problem Based LKS can improve students' critical thinking skills in ecosystem material.

Keywords : STAD Model, Problem Based LKS, Critical Thinking Ability

\section{PENDAhULUAN}

Dari hasil observasi, proses belajar mengajar IPA yang dijumpai di SMP Negeri 2 Jalaksana masih sering menggunakan metode konvensional yang menjadikan guru sebagai pusat kegiatan belajar mengajar satu arah dengan kurangnya interaksi antar siswa dan guru. Siswa pada umumnya hanya mendengarkan, membaca dan 
menghafal informasi yang diperoleh, sehingga konsep yang tertanam tidak kuat.Dari metode ini hasil yang dicapai kurang maksimal dan keaktifan siswa serta potensi yang ada pada siswa kurang terlihat, selain itu sebagaian besar siswa juga kurang termotivasi untuk berpikir dalam penyelesaian suatu permasalahan.

Dilihat dari permasalahan di atas ternyata aspek keterampilan berpikir kritis mulai dari memberikan penjelasan sederhana, membangun keterampilan dasar, menyimpulkan, memberikan penjelasan lebih lanjut, dan mengatur strategi, belum ditumbuh kembangkan sebagai kompetensi yang harus dimiliki dikalangan siswa, sehingga sangat jarang ditemukan siswa secara proaktif mengajukan permasalahan dan sangat sedikit juga siswa yang berani menjawab permasalahan yang diajukan dalam pembelajaran, hal ini menyebabkan proses berpikir siswa tidak mengalami peningkatan.

Croanbach (dalam Yatim, R, 2009) menyatakan bahwa belajar itu merupakan perubahan perilaku sebagai hasil dari pengalaman. Belajar adalah suatu cara mengamati, membaca, meniru, mengintimidasi, mencoba sesuatu, mendengar dan mengikuti arah tertentu. Demikian dapat dijelaskan bahwa belajar adalah suatu cara mendapatkan sesuatu melalui proses untuk mendapatkan sesuatu yang disebut dengan hasil belajar.

Berpikir kritis adalah proses yang melibatkan operasi mental secara induksi, deduksi, klasifikasi dan penalaran. Menurut Ennis dan Fogarty serta McTighe (dalam Sitty, R, 2013) menyatakan bahwa berpikir kritis merupakan cara berpikir reflektif yang masuk akal atau berdasarkan nalar untuk memutuskan apa yang akan dikerjakan dan diyakini.

Menurut Sitty, R. (2013) keterkaitan berpikir kritis dalam belajar adalah perlunya mempersiapkan siswa agar menjadi pemecah masalah yang tangguh, pembuat keputusan yang matang, dan orang yang tak pernah berhenti belajar. Penting bagi siswa untuk menjadi seorang pemikir materi sejalan dengan meningkatnya permasalahan di masa yang akan datang yang membutuhkan orang-orang handal yang memiliki kemampuan berpikir kritis.

Selain itu pembelajaran juga harus merupakan suatu proses untuk menghantarkan siswa menuju ke tingkat yang lebih dewasa dalam bertindak, bepikir serta mampu menjalin kerja sama dengan orang-orang sekitarnya (kooperatif) sehingga mereka mampu menyelesaikan segala macam permasalahan dalam kehidupannya secara bersama-sama.

Solusi yang harus dilakukan guru untuk meningkatkan kualitas proses pembelajaran serta hasil belajar siswa khususnya dalam keterampilan berpikir kritis adalah memperbaiki proses pembelajaran dengan menggunakan metode pembelajaran yang sesuai. Inovasi proses pembelajaran salah satunya adalah dengan menerapkan pembelajaran kooperatif (Cooperative Learning).

Menurut Slavin (dalam Isjoni, 2010) menyatakan bahwa pembelajaran kooperatif ini menggalakkan siswa untuk berinteraksi secara aktif dan positif dalam kelompok. Tujuan dibentuknya kelompok yakni memberikan kesempatan kepada siswa untuk terlibat secara aktif dalam proses berpikir. Salah satu model pembelajaran kooperatif yang memungkinkan siswa untuk terlibat secara aktif dalam kegiatan berpikir dan belajar secara berkelompok yaitu Student Teams Achievement Division (STAD).

Meski demikian model pembelajaran kooperatif memang membuat siswa menjadi lebih aktif dalam menggunakan kemampuan berpikirnya, namun LKS yang digunakan oleh guru masih berupa soal latihan saja, dan belum berorientasi pada kemampuan berpikir kritis siswa sehingga kemampuan berpikir kritis siswa masih rendah.

Berdasarkan kondisi tersebut salah satu alternatif yang diharapkan dapat melatih siswa untuk berpikir tingkat tinggi adalah dengan adanya LKS berbasis masalah sehingga siswa dapat menggunakan LKS ini untuk mengembangkan kemampuan berpikir kritisnya.

Model pembelajaran kooperatif STAD memiliki beberapa kelebihan sehingga sangat tepat digunakan pada materi Ekosistem.Model STAD yang disertai dengan penggunaan LKS berbasis masalah ini diharapkan dapat meningkatkan peran serta dan keaktifan siswa dalam kegiatan belajar mengajar, dapat meningkatkan kemampuan berpikir kritis siswa dalam pembelajaran IPA dan melatih kemandirian siswa dalam pembelajaran.

Adapun tujuan penelitian yang ingin dicapai dalam penelitian ini adalah untuk menganalisis penerapan model tipe Student Teams Achievement Division melalui LKS berbasis masalah terhadap peningkatan kemampuan berpikir kritis siswa pada materi Ekosistem di Kelas VII SMP Negeri 2 Jalaksana. 
Quagga: Jurnal Pendidikan dan Biologi

Volume 10, Nomor 2, Juli 2018

\section{METODOLOGI PENELITIAN}

Penelitian eksperimen dilaksanakan di SMP Negeri 2 Jalaksana dengan menggunakan penelitian quasi eksperiment dengan desain PrePost Control Group Design.Pengambilan sampel dilakukan dengan teknik Cluster random sampling yaitu dari 7 kelas yang ada diambil 2 kelas sebagai sampel.Sampel penelitian berjumlah 56 orang siswa yang terdaftar pada semester II kelas VII SMP Negeri 2 Jalaksana. Siswa kelas VII D sebagai kelas eksperimen diberikan pembelajaran dengan model pembelajaran STAD melalui LKS Berbasis Masalahsedangkan kelas VII C sebagai kelas kontrol diberikan pembelajaran STAD tanpa bantuan LKS berbasis masalah, seperti desaign penelitian dibawah ini:

menurut Sugiyono (2010), yaitu:

\begin{tabular}{|llll|}
\hline $\mathrm{R}$ & $\mathrm{O}_{1}$ & $\mathrm{X}$ & $\mathrm{O}_{2}$ \\
$\mathrm{R}$ & $\mathrm{O}_{3}$ & & $\mathrm{O}_{4}$ \\
\hline
\end{tabular}

Keterangan:

$\mathrm{O}_{1}$ : Tes awal (pretest) Kelas Eksperimen

$\mathrm{O}_{2}$ : Tes akhir (posttest) Kelas Eksperimen

$\mathrm{O}_{3}$ : Tes awal (pretest) Kelas Kontrol

$\mathrm{O}_{4}$ : Tes akhir (Posttest) Kelas Kontrol

$X$ : Model pembelajaran STAD melalui LKS berbasis masalah

\section{Analisis Data Kriteria Kelayakan LKS Berbasis Masalah}

Data kualitatif yang dikumpulkan berdasarkan penilaian kelayakan perangkat oleh tim ahli dan respon siswa mencakup lima kategori yakni: 5 untuk kategori sangat baik, 4 untuk ktegori baik 3 untuk kategori cukup, 2 untuk kategori kurang baik dan 1 untuk kategori tidak baik. Aspekaspek yang diamati dan dinilai oleh validator berdasarkan angket validasi yang dibuat peneliti padamasing-masing indikator, yaitu meliputi penyusunan LKS, tata bahasa dan penyajian.Selanjutnya, data penilaian angket validasi tim ahli dan angket validasi respon siswa pembelajaran ditabulasi dan dihitung rata-rata persentase skor, kemudian diubah menjadi nilai dalam bentuk kriteria menurut Arikunto (dalam Heri, S, 2015).

Adapun kriteriatersebut dapat dilihat pada tabel 1.berikut ini:

Tabel 1. Kriteria Kelayakan Penilaian LKS Berbasis Masalah

\begin{tabular}{lrc}
\hline No & Persentase Skor & Kriteria \\
\hline $\mathbf{1}$ & $83 \%<$ skor $\leq 100 \%$ & Sangat Baik \\
\hline
\end{tabular}

p-ISSN 1907-3089, e-ISSN2651-5869

https://journal.uniku.ac.id/index.php/quagga

\begin{tabular}{lll}
\hline $\mathbf{2}$ & $67 \%<$ skor $\leq 83 \%$ & Baik \\
$\mathbf{3}$ & $51 \%<$ skor $\leq 66 \%$ & Cukup Baik \\
$\mathbf{4}$ & $35 \%<$ skor $\leq 50 \%$ & Kurang Baik \\
$\mathbf{5}$ & $20 \%<$ skor $\leq 40 \%$ & Tidak Baik \\
\hline
\end{tabular}

\section{Analisis Data Kemampuan Berpikir Kritis}

Data pre-post kemampuan berpikir kritis yang diperoleh ditabulasi kemudian dihitung nilai rataratanya dan kenaikannya. Data posttest kemampuan berpikir kritis digunakan untuk menguji hipotesis. Uji hipotesis dilakukan untuk mengetahui: Apakah terdapatpeningkatan kemampuan berpikir kritis siswa dengan penerapan model STAD melalui LKS berbasis masalah pada materi ekosistem di kelas VII SMP Negeri 2 Jalaksana. Uji hipotesis penelitian menggunakan uji-t dengan bantuan program komputer Excel 2007 pada taraf signifikan 5\%. Kriteria pengujian hipotesis: Ho ditolak apabila thitung > ttabel atau nilai $\mathrm{p}>0,05$ maka Ho diterima, demikian sebaliknya jika $\mathrm{p}<0,05$ maka Ho ditolak.

\section{HASIL DAN PEMBAHASAN}

Hasil penelitian yang dilakukan di SMPN 2 Jalaksana menunjukkan bahwa kelas eksperimen memiliki kemampuan berpikir kritis lebih tinggi dibandingkan kelas kontrol hal ini disebabkan karena pembelajaran dengan menggunakan model STAD memberi kebebasan kepada siswa untuk membangun pengetahuannya sendiri dan guru hanya bertindak sebagai fasilitator, dengan adanya diskusi menggunakan LKS Berbasis Masalah yang didalamnya terdapat 5 indikator pada masing-masing soal meliputi mengidentifikasi permasalahan, merumuskan masalah, mencari alternatif-alternatif solusi pemecahan masalah, memilih alternatif solusi yang terbaik dan menyimpulkan hasil pemecahan masalah yang sesuai dengan konsep ekosistem. Dalam proses pembelajarannya siswa akan lebih aktif dalam hal memecahkan masalah, aktif dalam mencari data atau keterangan yang tentunya dapat digunakan untuk memecahkan masalah melalui penyelidikan langsung, bertanya, diskusi dan mencari berbagai literature yang mendukung dalam memecahkan masalah yang ada pada LKS Berbasis Masalah. Hal ini sejalan dengan pendapat Santrock dalam Lia, A (2015) yang menyatakan bahwa untuk mampu berpikir kritis anak harus bisa mengambil peran aktif dalam proses pembelajaran.

Berdasarkan hasil pretest yang diberikan pada kelas ekpserimen dan kelas kontrol diperoleh hasil bahwa tidak terdapat perbedaan pada 
Quagga: Jurnal Pendidikan dan Biologi

Volume 10, Nomor 2, Juli 2018

kemampuan awal siswa baik pada kelas eksperimen maupun kelas kontrol yang artinya siswa memiliki kemampuan awal yang sama, hal itu terlihat pada uji $\mathrm{t}$ pretest. Rata-rata keseluruhan nilai pretest siswa pada kelas eksperimen dan pada kelas kontrol tidak jauh berbeda seperti pada tabel 2:

Tabel 2. Rata-rata pretest

\begin{tabular}{ccr}
\hline \multirow{2}{*}{ Kelas } & Jumlah & \multirow{2}{*}{ Rata-rata } \\
\hline Kontrol & 28 & 46,93 \\
Eksperimen & 28 & 48,07 \\
\hline
\end{tabular}

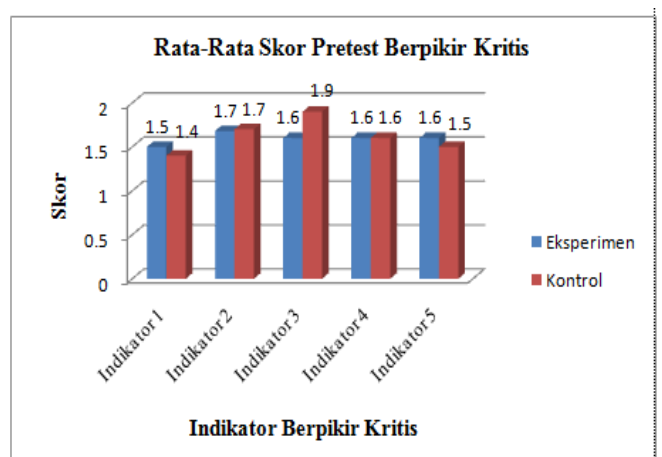

Gambar 1. Analisis Soal Uraian Pretest Kelas Eksperimen dan Kelas Kontrol

Dari tabel 2 dan gambar 1,analisis hasil pretest siswa berdasarkan indikator kemampuan berpikir kritis, terlihat persentase hasil pretest tiap indikator kemampuan berpikir kritis pada kelas eksperimen dan kelas kontrol tidak terlihat jauh berbeda, sejalan dengan uji t pretest yang dapat dilihat pada tabel 3:

Table 3. Uji t Pretest

\begin{tabular}{cccc}
\hline Kelas & $\boldsymbol{t}_{\text {hitung }}$ & $\boldsymbol{t}_{\text {tabel }}$ & Kesimpulan \\
\hline $\begin{array}{l}\text { Eksperimen } \\
\text { dan Kontrol }\end{array}$ & 0,6 & 2,005 & Ho diterima \\
\hline
\end{tabular}

Berdasarkan tabel 3, hasilnya menyimpulkan bahwa Ho diterima dan $\mathrm{H}_{1}$ ditolak karena $\mathrm{t}_{\text {hitung( }(0,6)}<\mathrm{t}_{\text {tabel }(2,005)}$, yang artinya kedua kelompok sampel baik kelas eksperimen maupun kelas kontrol tidak memiliki perbedaan yang signifikan (setara).

Sementara itu dilihat dari nilai posttest yang diberikan pada kelas eksperimen dan kelas kontrol setelah mendapatkan perlakuan proses pembelajaran yang berbeda didapat hasil ratarata nilai yang cukup berbeda seperti pada tabel 4:
p-ISSN 1907-3089, e-ISSN2651-5869

https://journal.uniku.ac.id/index.php/quagga

Tabel 4. Rata-rata posttest

\begin{tabular}{ccc}
\hline \multirow{2}{*}{ Kelas } & Jumlah & \multirow{2}{*}{ Rata-rata } \\
\hline Kontrol & 28 & 58,2 \\
Eksperimen & 28 & 72,2 \\
\hline
\end{tabular}

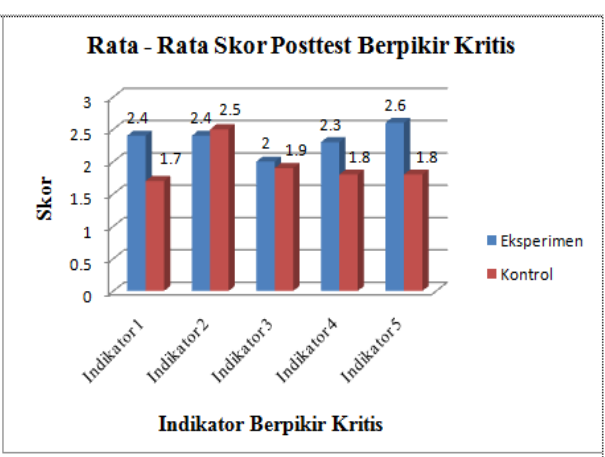

Gambar 2. Analisis Soal Uraian Pretest Kelas Eksperimen dan Kelas Kontrol

Berdasarkan tabel 4 dan gambar 2 memperlihatkan bahwa penerapan model pembelajaran STAD melalui LKS Berbasis Masalah berpengaruh terhadap kemampuan berpikir kritis siswa dengan rata-rata posttest kelas eksperimen lebih tinggu dibanding kelas kontrol. Pernyataan tersebut sejalan dengan uji $\mathrm{t}$ posttest yang dapat dilihat pada tabel 5:

Tabel 5. Uji t Posttest

\begin{tabular}{cccc}
\hline Kelas & $\boldsymbol{t}_{\text {hitung }}$ & $\boldsymbol{t}_{\text {tabel }}$ & Kesimpulan \\
\hline $\begin{array}{c}\text { Eksperimen } \\
\text { dan Kontrol }\end{array}$ & 4,5 & 2,005 & $\begin{array}{c}\text { Ho ditolak } \\
\mathrm{H}_{1} \text { diterima }\end{array}$ \\
\hline
\end{tabular}

Tabel 5 menyimpulkan bahwa Ho ditolak dan $\mathrm{H}_{1}$ diterima karena $\mathrm{t}_{\text {hitung(4,5) }}>\mathrm{t}_{\text {tabel(2,005), yang }}$ artinya terdapat peningkatan kemampuan berpikir kritis siswa pada materi Ekosistem menggunakan model Pembelajaran STAD Melalui LKS berbasis masalah.

Selanjutnya untuk melihat peningkatan kemampuan berpikir kritis sebelum dan setelah diberi perlakuan dari nilai pretest ke posttest pada kelas eksperimen dan pada kelas kontrol dilanjutkan uji $\mathrm{N}$-gain. Setelah dilakukan uji $\mathrm{N}$ gain didapatkan hasil indeks gaindengan hasil indeks gain kelas ekperimen yaitu 0,48 yang termasuk dalam kriteria sedang dan untuk kelas kontrol yaitu 0,22 yang termasuk kedalam kriteria rendah.

Hal diatas sejalan dengan analisis peningkatan persentase tiap indikator kemampuan berpikir kritis siswa pada kelas eksperimen yang lebih baik dibandingkan dengan 
kelas kontrol, karena pada kelas eksperimen yang menerapakan model pembelajaran STAD Melalui LKS berbasis masalah dihadapkan pada permasalahan kontekstual. Pembelajaran kontekstual merupakan desain pembelajaran yang menyediakan cara bagi siswa untuk menghubungkan konten pembelajaran yang didapatnya dengan dunia luar yang menumbuhkan kemampuan berpikir kritisnya (Wishler dalam Hasruddin dkk, 2015).

Pada kelas eksperimen yang menerapkan model pembelajaran STAD Melalui LKS berbasis masalah juga mengharuskan siswa untuk mengidentifikasi permasalahan, merumuskan masalah, mencari alternatif-alternatif solusi pemecahan masalah, memilih alternatif solusi yang terbaik dan menyimpulkan hasil pemecahan masalah yang dihubungkan dengan konteks materi yang diajarkan di dalam kelompok heterogen (Wati D.K, 2014).Sehingga dapat disimpulkan bahwa siswa pada kelas eksperimen dituntut untuk mengembangkan keterampilan berpikir kritisnya dalam menyelesaikan masalah. Berbeda dengan kelas kontrol yang menerapkan model pembelajaran STAD tanpa bantuan LKS Berbasis Masalah, siswa hanya dihadapkan pada fase-fase yang terdapat pada model pembelajaran STAD dan LKS yang berisi pertanyaanpertanyaan singkat saja. Penggunaan LKS diskusi yang berisi pertanyaan singkat tidak terlalu membantu siswa dalam berpikir kritis. Senada dengan pendapat yang diungkapkan oleh Burris, S et al., (2007) dalam penelitiannya bahwa siswa yang dihadapkan dengan pembelajaran berbasis masalah menunjukkan peningkatan yang lebih besar berpikir kritisnya daripada siswa yang diajarkan dengan menggunakan strategi konvensional.

Untuk mendukung adanya peningkatan kemampuan berpikir kritis siswa pada kelas eksperimen maupun kelas kontrol dapat dilihat pada gambar 3 dan 4 .

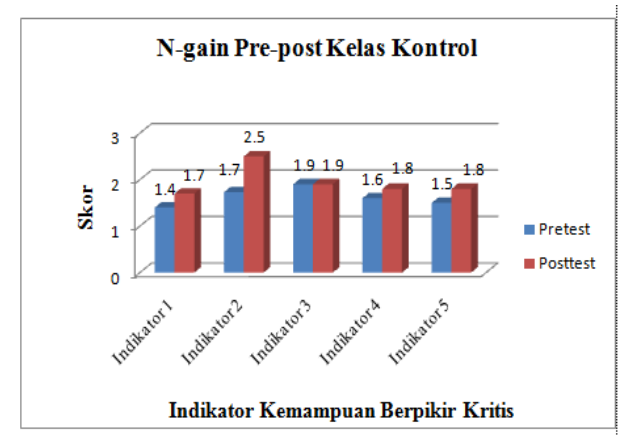

Gambar 3. N-gain Pretest - Posttest Kelas Kontrol

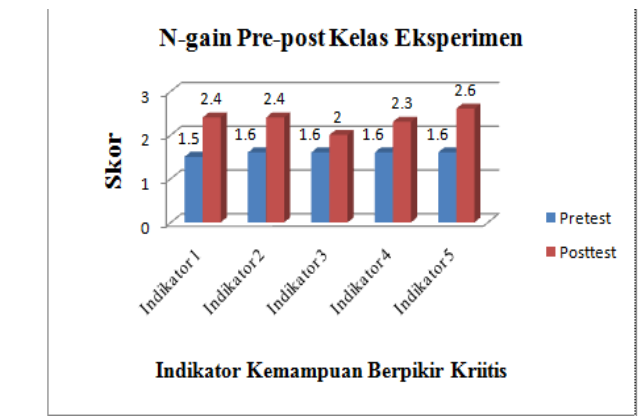

Gambar 4. N-gain Pretest - Posttest Kelas Eksperimen

Berdasarkan gambar 3 dan 4 dijelaskan bahwa terjadi peningkatan kemampuan berpikir kritis pada kelas eksperimen yang menerapkan model pembelajaran STAD melalui LKS berbasis masalah dengan rata-rata skor yang diperoleh yaitu 2 sampai 2,5 dimana siswa mampu mengembangkan kemampuan berpikir kritis dengan semua indikator yang mengalami peningkatan. Demikian kelas kontrol pun mengalami peningkatan kemampuan berpikir kritis tiap indikatornya, namun peningkatan kemampuan berpikir kritis siswa di kelas kontrol berada pada rata-rata 1 sampai 1,5, dimana skor 1 menunjukkan siswa belum mampu mengembangkan kemampuan berpikir kritisnya.

Selain penilaian tes uraian yang mendukung terjadinya peningkatan kemampuan berpikir kritis siswa, hasil analisis angket yang diberikan kepada siswa setelah proses pembelajaran berlangsung juga menunjukkan ketertarikan siswa dalam proses belajar yang mencapai persentase $87 \%$, yang artinya model tersebut dapat membantu dirinya untuk memahami materi lebih cepat dan mengembangkan kemampuan berpikir kritisnya.

Selain itu penilaian lembar observasi guru maupun siswa juga menunjukkan keterlaksanaan proses pembelajaran dengan penerapan model STAD melalui LKS Berbasis Masalah pada kelas eksperimen yang mencapai $89 \%$, artinya proses pembelajaran hampir seluruhnya terlaksana mulai dari pendahuluan, fase 1 persentasi materi, fase 2 pembentukan kelompok, fase 3 pemberian kuis, fase 4 menghitung skor kemajuan individu, fase 5 pemberian reward dan tahap terakhir yaitu penutup.

Hasilnya baik kelas kontrol maupun kelas eksperimen sama-sama mengalami peningkatan karena kedua sampel tersebut diberi perlakuan penerapan model STAD. Hal tersebut didukung dengan pendapat yang disampaikan oleh Borrich 
dalam penelitian yang dilakukan oleh Khan, G.N et al., 2011 bahwa STAD merupakan pembelajaran kooperatif yang dapat membentuk sikap dan nilai-nilai, membangun perilaku prososial, membangun identitas yang koheren, meningkatkan kemampuan berpikir kritis siswa, penalaran dan perilaku pemecahan masalah. Husamah dan pantiwati (2014) juga menambahkan dalam penelitiannya bahwa STAD merupakan pembelajaran kooperatif yang dapat meningkatkan kualitas pembelajaran termasuk aktivitas belajar, keterampilan, karya ilmiah dan khususnya kemampuan berpikir kritis.

Meski demikian, peningkatan kemampuan berpikir kritis pada kelas eksperimen kenyataanya lebih tinggi dibandingkan dengan kelas kontrol karena adanya penggunaan LKS berbasis masalah. Hal tersebut didukung penelitian yang dilakukan oleh Nisa D.K, dkk (2015) bahwa LKS berbasis masalah membuat siswa lebih mengandalkan kemampuan berpikir mereka khususnya berpikir kritisnya, akibatnya siswa menjadi lebih aktif dalam mencari dan menemukan sendiri jawaban dari berbagai informasi untuk memecahkan masalah yang telah ditentukan tanpa mengandalkan guru sebagai sumber informasi.

Dari hasil analisis tes uraian, analisis LKS berbasis masalah, analisis angket dan lembar observasi sebagai data pelengkap, terlihat bahwa semua data yang diperoleh dapat dikatakan baik. Atau dengan kata lain penerapan model pembelajaran STAD melalui LKS berbasis masalah dapat dijadikan suatu alternatif pembelajaran untuk meningkatkan kemampuan berpikir kritis siswa.

\section{SIMPULAN}

Berdasarkan hasil analisis data dan pengujian hipotesis penelitian yang telah dilaksanakan maka, peneliti menyimpulkan secara keseluruhan hasil penelitian yang dilakukan yaitu, hasil uji Ho ditolak dan $\mathrm{H}_{1}$ diterima karena $\mathrm{t}_{\text {hitung(4,5) }}>$ $\mathrm{t}_{\text {tabel(2,005), yang artinya terdapat peningkatan }}$ kemampuan berpikir kritis siswa pada materi Ekosistem menggunakan model Pembelajaran STAD Melalui LKS berbasis masalah. Hasil tersebut diperoleh dari nilai rata-rata posttest kemampuan berpikir kritis siswa pada kelas eksperimen sebesar 72,2 dan kelas kontrol 58,2 didukung pula dengan rata-rata indeks $\mathrm{N}$-gain kelas eksperimen yang lebih tinggi yaitu 0,48 pada kriteria sedang, sedagkan kelas kontrol hanya mencapai 0,22 dan berada pada kriteria rendah.

\section{REFERENSI}

Burris, S et al,. (2007). "Effect Of Intructional Strategy On Critical Thinking And Conttent Knowledge: Using ProblemBased Learning In The Secondar Classroom". Journal of Agricultural Education.(Online), 48, (1).106-116. http://www.jaeonline.org/attachments/artic le/193/Burris.pdf.Diakses 10 Mei 2016.

Hasruddin, dkk. (2015). "Application of Contextual Learning to Improve Critical Thinking Ability of Students in Biology Teaching and Learning Strategies Class". International Journal of Learning, Teaching and Educational Research.(Online).11, $\quad$ (9).109116.http://www.ijlter.org/index.php/ijlter/a rticle/view/317.Diakses 10 Mei 2016.

Heri, S. (2015). Pengembangan LKS IPA Berbasis Problem Based Learning Tema Pencemaran Lingkungan Guna Menumbuhkan Kemandirian Siswa. Skripsi.Fakultas Matematika dan Ilmu Pengetahuan Alam, Universitas Semarang.(Online).http://lib.unnes.ac.id/2 1066/1/4001411038-S.pdf.Diakses 10 Februari 2016.

Husamah dan Pantiwati. (2014). "Cooperative Learning STAD-PJBL: Motivation, Thinking, Skills, and Learning Outcomes Of Biology Department Students". International Journal of Education Learning and Development.(Online).2, (1).77-94. http://www.eajournals.org/wpcontent/uploads/.Diakses 10 Mei 2016.

Isjoni.(2010). Cooperative Learning.Bandung : Alfabeta. Koes, I. (2014). Ekologi Kesehatan. Bandung : Alfabeta.

Khan, G.N, et al,.(2011). "Effect of Student's Team Achievement Division (STAD) on Academic Achievement of Students".Journal International Education.(Online), 7, (12).1-5. www.ccsenet.org/journal/index.php/ass/art icle/view/13435 Diakses 10 Mei 2016.

Lia, A. (2015). Penerapan Model PBL Untuk Meningkatkan Keterampilan Berpikir Kritis Ditinjau Dari Kemampuan Akademik Siswa Pada Materi Biologi. Skripsi.Fakultas Keguruan dan Ilmu 
Quagga: Jurnal Pendidikan dan Biologi

Volume 10, Nomor 2, Juli 2018
p-ISSN 1907-3089, e-ISSN2651-5869

https://journal.uniku.ac.id/index.php/quagga

Pendidikan, Universitas Kuningan, Kuningan.(Tidak dipublikasikan).

Nisa K.D. (2015). "Pengaruh Penggunaan LKS Berbasis Masalah Terhadap Kemampuan Berpikir Kritis Siswa".Jurnal Penelitian Pendidikan. (Online).5, (3).111.http://jurnal.fkip.unila.ac.id/index.php/J BT/article/view/9077. Diakses 11 Februari 2016.

Sitty, R. (2013).Penerapan Model Cooperative Learning TGT (Teams Games Tournament) pada Materi Pencemaran Lingkungan Untuk Meningkatkan Motivasi Belajar dan Kemampuan Berfikir Kritis Siswa.Tesis.Fakultas Keguruan dan Ilmu Pendidikan, Universitas Kuningan, Kuningan.(Tidak dipublikasikan).

Sugiyono.(2010). Metode Penelitian Pendidikan. Bandung : Alfabeta.

Yatim, R. (2009). Paradigma Baru Pembelajaran. Jakarta : Kharisma Putra Pratama.

Wati D.K. (2014). Penggunaan LKS Berbasis Masalah Untuk Meningkatkan Hasil Belajar Siswa Pada Konsep Virus Dan Monera.Skripsi.Fakultas Ilmu Tarbiyah dan Keguruan, UIN Syarif Hidayatullah.(Online).http://repository.uin jkt.ac.id/dspace/handle/123456789/24815? mode=full. Diakses 10 Februari 2016. 